\title{
Considerations on the Influence of Zinc on Infectious Diseases in Children
}

\author{
NICOLETA NEGRUT ${ }^{1}$, MARIUS RUS ${ }^{1}$, CARMEN PANTIS ${ }^{1}$, OCTAVIAN MAGHIAR ${ }^{1}$, \\ CARMEN DELIA NISTOR CSEPPENTO ${ }^{1}$, DIANA UIVAROSAN ${ }^{1}$, \\ ANA MARIA ALEXANDRA STANESCU,"*, DAN ARSENIE SPINU², \\ OVIDIU FRATILA ${ }^{*}$, SIMONA BUNGAU ${ }^{1}$ \\ ${ }^{1}$ University of Oradea, Faculty of Medicine and Pharmacy, 1 Decembrie Sq., 410073 Oradea, Romania \\ ${ }^{2}$ University of Medicine and Pharmacy "Carol Davila", 8 Eroii Sanitari St., Bucharest, 050474 Bucharest, Romania
}

Abstract: Zinc modulates the human body defence against infections. Mild and medium deficiency in this mineral appears usually sub-clinically, being mistaken for other diseases, but the severe form can be fatal. The purpose of the study was to determine the plasma zinc concentration (PZC) for the most common infectious pathology in children. Zinc was measured in plasma using direct colorimetric assay based on the 5-Br-PAPS method (CV\% 0.98-4.64\%). In the paediatric patients, 0-3 years old, the PZC values were 15.20 $1.37 \mu \mathrm{mol} / \mathrm{L}$, with limits ranging between 13.05-20.6 $\mu \mathrm{mol} / \mathrm{L}$, the values falling within normal limits and proving the absence of zinc deficiency in the investigated population. During 3 years of follow up, 137 healthy children presented low values of plasma zinc concentration if they had acute lower respiratory infections, acute otitis media or giardiasis in past medical history. There were not found significant differences in case of children with viral or bacterial acute diarrheal diseases or viral exanthemas. In the present study, the children exposed to severe, complicated or chronic forms of infectious diseases were predisposed to low plasma zinc concentrations.

Keywords: plasma zinc concentration, infectious diseases, children

\section{Introduction}

Zinc modulates the nonspecific and specific immune response, at the human body level, playing a role in the metabolism of nucleic acids and in the enzymatic activity (catalytic, regulatory, structural), being necessary for growth and development processes.

So far, medical studies have demonstrated the role of zinc in maintaining the integrity and permeability of the cell membrane, the integrity of intercellular junctions and of the physiological organization of the intestinal cells' cytoskeleton, associated with the role of preventing migration for polymorphonuclear cells [1]. At the level of epithelial barriers, the role of zinc in the nonspecific immune response has been demonstrated as breaking down the intercellular junctional complexes and disorganizing the cytoskeleton, following the zinc deprivation of the organism [2]. Also, low concentrations of zinc were determined at the mucous membranes level in the case of patients with intestinal permeability chronic disorders. Zinc deficiency causes massive neutrophil migration by altering the zonula occludens, and by chemotaxis [3].

Alteration of phagocytosis and antigenic presentation at the level of macrophages; decreased maturation and expression of major histocompatibility complex (MCH) class II, by dendritic cells; alteration of cytokine production in mast cells are other negative effects secondary to the decrease in zinc level [4]. Ten days of zinc treatment, in case of Enterotoxigenic Escherichia Coli infection in children, determines an increase in the innate immune response, and persistence of it for the next 3 months after therapy [5]. The increased immune response is obtained by the synthesis of $\mathrm{C}_{3}$ complement, stimulation of polymorphonuclear cell phagocytosis, monocytes and $\mathrm{T}$ cell function $[6,7]$.

\footnotetext{
*email: alexandrazotta@yahoo.com,ofratila@uoradea.ro
} 
The cellular immune response induces the elimination of cells altered by infection or malignant degeneration. The function is performed by cytotoxic T cells, natural killer (NK) cells and killer cells (K). Immunocompetent $\mathrm{T}$ cells come from medullary multipotent stem cells by migration and differentiation at the thymus level. The thymus undergoes a process of atrophy under the influence of endogenous glucocorticoids. Zinc deficiency increases glucocorticoid hormone concentration, secondary stimulation of thymocyte apoptosis, thymic atrophy and decreased thymic lymphopoiesis with a preserved myelopoiesis [8,9]. Myelopoiesis remains unaffected by increased levels of corticosteroids, due to the presence of $20 \alpha$-hydroxysteroid dehydrogenase [10].

Associated zinc deficiency causes a decrease in the number of $\mathrm{CD}_{8+}$, and $\mathrm{CD}_{73}+$ cells, considered cytotoxic $\mathrm{CD}_{8}+$ cells precursors [11]. Zinc is required for the activity of thymic peptide thymulin, responsible for the cell differentiation with the formation of T-helper $1\left(\mathrm{TH}_{1}\right)$ cells. Thymulin becomes biologically active in the presence of zinc $[12,13]$. Cytokines and zinc induced differentiation of native $\mathrm{CD}_{4+}$ cells into $\mathrm{TH}_{1}$ and $\mathrm{TH}_{17}$. The zinc blocks the genetic activity of $\mathrm{STAT}_{3}$ (Signal Transducer and Activator of Transcription 3), responsible for $\mathrm{CD}_{4+}$ cells transformation into $\mathrm{TH}_{17}$ cells. Secondarily, the synthesis decrease is followed by a reduction in inflammatory and autoimmune processes mediated by them. The imbalance between $\mathrm{TH}_{1}$ cells (influenced by zinc deficiency) and $\mathrm{TH}_{2}$ (not zinc-dependent) caused disequilibrium of the cytokines' synthesis, with the decrease of interferon-gamma (IFN- $\gamma$ ), tumour necrosis factor-alpha (TNF- $\alpha$ ), and interleukins-2 ( $\left.\mathrm{IL}_{2}\right)$ (synthesized by $\mathrm{TH}_{1}$ cells), compared to the preservation of $\mathrm{IL}_{4,5,6,10}$ (synthesized by $\mathrm{TH}_{2}$ cells). Decreased IFN- $\gamma$ production inhibits T cell growth and differentiation, as well as TNF- $\alpha$ secretion.

Secondary of this, the cytotoxic activity of macrophages, T cells and NK are inhibited, followed by the increased susceptibility of organisms to infections. The low concentrations of TNF- $\alpha$ cause decreased neutrophil activation and $B$ cell differentiation (mediated by $\mathrm{IL}_{6}$ ). Lower $\mathrm{IL}_{2}$ concentration is responsible for decreased $\mathrm{T}$ cell proliferation, $\mathrm{B}$ cell multiplication and differentiation, reduced monocyte and $\mathrm{K}$ cell activity [14]. The $\mathrm{K}$ and NK cells perform cell recognition and destruction not dependent on MHC class I [15]. NK cells destroy virus-infected cells or tumour cells. Zinc stimulates proliferation and differentiation of $\mathrm{NK}$ cells from $\mathrm{CD}_{34}$ precursors and their cytolytic activity [16].

Zinc is important in the proliferation process of $\mathrm{B}$ cells, responsible for the humoral immune response [17]. The imbalance between cytokines causes the disruption of antibody synthesis. The antiapoptotic role of zinc is demonstrated by the formation of zinc-thiolate complex which has a protective role for cellular proteins against reactive oxygen species, as well as blocking the activation of caspase-3 in the caspase cascade pathway [3,9]. Moreover, zinc deficiency is increasing the glucocorticoids production, the hormones playing a proapoptotic role for lymphocyte precursors $[8,18]$. Secondary to zinc deficiency, $\mathrm{T}$ and B-cell lymphopenia occur.

Zinc is required for deoxyribonucleic acid (DNA) synthesis, ribonucleic acid (RNA) transcription, cell division and cell activation [9]. During infections, zinc is introduced into the hepatocyte by a transporter protein (Zrt- and Irt-like proteins - ZIP 14) and stored in the liver in the form of metallothionein (MT). Hypozincemia, secondary to hepatocyte storage, deprives microorganisms of the zinc required for growth and multiplication [19] ${ }^{\text {Error! Bookmark not defined. }}$

Also, zinc has a preventive and therapeutic role in acute diarrhoea in children, leading to a decrease of the duration of acute episodes, of the need for oral rehydration salts, of the stool volume and of mortality rate [20, 21-23]. Giardia lamblia most commonly infects children under 5 years of age, causing a decrease in intestinal absorption of the minerals, most commonly for zinc. Zincemia, in children infected with this parasite, has been shown to be lower compared to healthy subjects [24]. As a result, the use of zinc in the treatment of these children can prevent zinc deficiency. Some studies have shown a decrease in the incidence of Giardia lamblia infection, probably by zinc mediated stimulation of $\mathrm{TH}_{1}$ lymphocyte activity [25,26]. Zinc has been shown to be effective in reducing the incidence of diarrhoea associated with Entamoeba histolytica [8]. In this infection, zinc acts by increasing the concentration of interferon $\gamma(\mathrm{IFN}-\gamma)$. IFN- $\gamma$ provides protection of the body in case of invasive forms of Entoamoeba hystolitica infection associated with diarrheal syndrome [27,28]. 
Zinc causes the decrease of the acute respiratory infections (ARI) incidence, has a favourable effect on their clinical picture as well as on the laboratory parameters and reduces morbidity due to ARI in the next 2 months after zinc supplementation, all effects being mediated by its immunomodulatory activity [5, 29, 30]. A Cochrane study, conducted in 2011 on 13 therapeutic trials and 966 participants, synthesized that zinc treatment decreases the duration of viral ARI, reduces the severity of the disease and the consumption of antibiotics [31-33]. The efficacy of zinc therapy is being evaluated in chronic hepatitis C, otitis media, leishmaniasis, leprosy, malaria and tuberculosis [9, 34].

The aim of this research was to evaluate the relationship between plasma zinc level and infectious diseases in the paediatric patients, highlighting new aspects in the recent literature data.

\section{Materials and methods}

The study population included 140 healthy children aged between 0 and 3 years. The subjects were presented within the infectious diseases department of the Dr. Gavril Curteanu Clinical Municipal Hospital, Oradea, Romania, during the period 2015-2017, for paraclinical investigations on request or for carrying out the compulsory check more than one year after an acute viral hepatitis A.

Patients excluded from the study were those with previous treatment with zinc, calcium, copper, iron, laxatives, antacids with magnesium and those without parents' written consent for inclusion in the study. Also, children who showed signs and symptoms suggestive of the disease at the time of examination were excluded from the study.

All children included in the study were medical examined on the day of blood sample collection. The samples were collected before eating, between 7.00-9.30 a.m. Becton-Dickinson vacutainer plasma tubes containing lithium heparin were used to obtain a plasma sample. During the procedure, the venous stasis to the upper limb was maintained for less than 1 minute. Immediately after, the vacutainer was rotated for up to 10 times. After 20 minutes, the sample was centrifuged at $4000 \mathrm{rpm}$ for 5 minutes. The plasma was transferred into closed plastic tubes and then into refrigerated bag for the transport to a private laboratory, for plasma zinc concentration (PZC) measurement. Plasma obtained on weekend was stored at a $-20^{\circ} \mathrm{C}$ to $-30^{\circ} \mathrm{C}$, maximum three days; PZC was determined in all patients using direct colorimetric assay based on the 5-Br-PAPS method (CV\% 0.98\% - 4.64\%).

This method is based on the reaction between zinc and 2-(5-Bromo-pyridylazo)-5-(N-propyl-Nsulfopropylamino)-phenol. As a result of this reaction, a red chelate complex is formed, directly proportional with the zinc concentration of the sample. The reading was performed at $540 \mathrm{~nm}$ wavelength, on the Beckman Synchron CX5 automatic analyzer (Beckman Coulter Inc., USA). The method used offers reference values between 9.8-16.8 $\mu \mathrm{mol} / \mathrm{L}$. According to the World Health Organisation (WHO), zinc deficiency was defined at values lower than $9.98 \mu \mathrm{mol} / \mathrm{L}$.

A questionnaire focused on demographic data (age, sex, provenance), and past medical history in the last six months (ARI, acute upper respiratory infection - AURI, acute lower respiratory infection ALRI; acute diarrheal disease - ADD, viral-ADD - V-ADD, bacterial-ADD - B-ADD; giardiasis) and in the last 3 months (acute otitis media - AOM; viral exanthem) was completed for each patient included in the study.

The research was performed according the WMA Declaration of Helsinki-Ethical Principles for Medical Research involving Human Subjects, the study being approved by the Ethical Council of the hospital mentioned above.

The sample size for the study was calculated taking into account the Cochran's formula applied to the total number of children under 3 years old, registered in Bihor county, Romania, in 2015; there were at least 96 cases, for a population of 31,210 children (data provided by the Bihor County Statistics Department). A total of 140 cases were included in the study.

The data were recorded into a primary database, using Microsoft Office Excel 2019, and subsequently statistically analysed. Detailed statistical analysis was done using IBM SPSS statistics application, version 26. The mean (M), standard deviation (SD) and statistical significance (p) tests (Student's t test) were determined. The $p$-value was considered significant if it was at least 0.05 . 


\section{Results and discussions}

During the studied period, 140 children were declared eligible; 3 children were excluded at the parents' request. A total of 137 cases remained in the study and their characteristics are presented in table 1 . The lot was relevant for a probability of $95 \%$.

Table 1. Characteristics of the subjects included in the study

\begin{tabular}{cc}
\hline Parameter & Study group $(\mathbf{N}=137)$ \\
\hline Male, $\mathrm{N}(\%)$ & $53(55.30)$ \\
\hline Age (months), $\mathrm{M} \pm$ DS & $19.5 \pm 10.48$ \\
\hline Provenance, $\mathrm{N}(\%)$ & $45(46.80)$ \\
\hline Past medical history & \\
\hline ARI & $64(46.71)$ \\
\hline AURI & $35(25.54)$ \\
\hline ALRI & $29(21.16)$ \\
\hline ADD & $50(36.49)$ \\
\hline V-ADD & $33(24.08)$ \\
\hline B-ADD & $17(12.41)$ \\
\hline Giardiasis & $38(27.73)$ \\
\hline Viral exanthema & $34(24.81)$ \\
\hline AOM & $27(19.70)$ \\
\hline
\end{tabular}

The PZC analysis showed values of $15.20 \pm 1.37 \mu \mathrm{mol} / \mathrm{L}$ for $\mathrm{M} \pm \mathrm{SD}$, in the study group. The minimum value of PZC recorded was $13.05 \mu \mathrm{mol} / \mathrm{L}$ and the maximum one was $20.6 \mu \mathrm{mol} / \mathrm{L}$.

$79.56 \%$ of the children had normal values of PZC according to their ages, ranging from 9.8 to 16.8 $\mu \mathrm{mol} / \mathrm{L}$, while in $20.44 \%$ of cases, the same parameter was above the normal upper limit. There were not recorded PZC values lower than the normal limit. Over $75 \%$ of the cases had values between $\mathrm{M} \pm 1$ SD $(75.18 \%)$ and $97.08 \%$ in the range $\mathrm{M} \pm 2 \mathrm{SD}$ (figure 1). The coefficient of variation for PZC was $9.01 \%$.

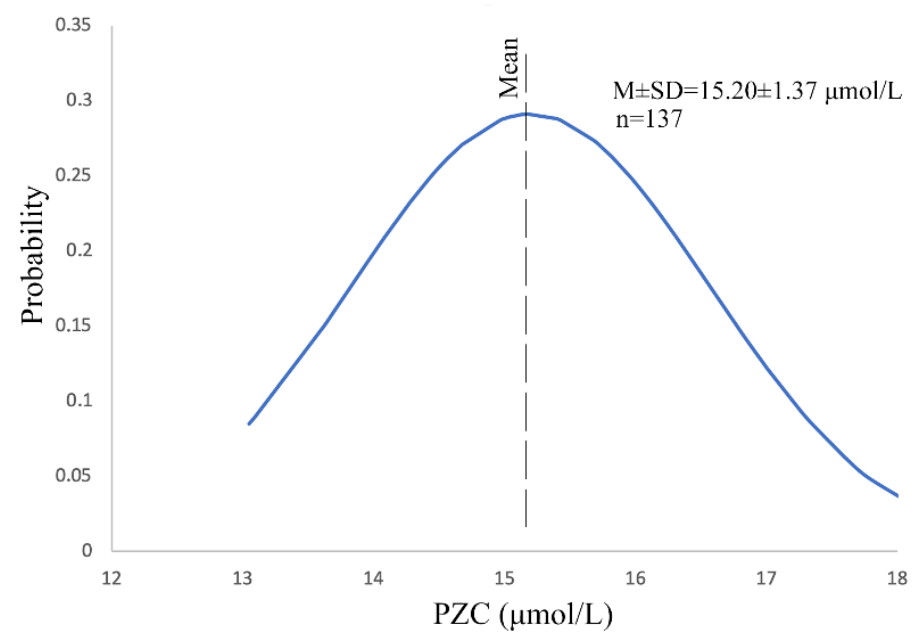

Figure 1. Gaussian distribution of PZC in healthy children

Subjects with at least one ALRI had lower PZC values, compared with those with only AURI $(14.10 \pm 0.75 \mu \mathrm{mol} / \mathrm{L}$ versus $15.97 \pm 1.43 \mu \mathrm{mol} / \mathrm{L})$ (figure 2$)$. The difference was statistically significant, $\mathrm{p}<0.001$. PZC values in the group of children with V-ADD in the last 6 months were $14.52 \pm 0.88 \mu \mathrm{mol} / \mathrm{L}$, compared with the values of $14.84 \pm 1.01 \mu \mathrm{mol} / \mathrm{L}$, recorded in the group who presented B-ADD in the last 6 months. The differences obtained were not statistically significant, $\mathrm{p}=0.24$ (figure 2). 


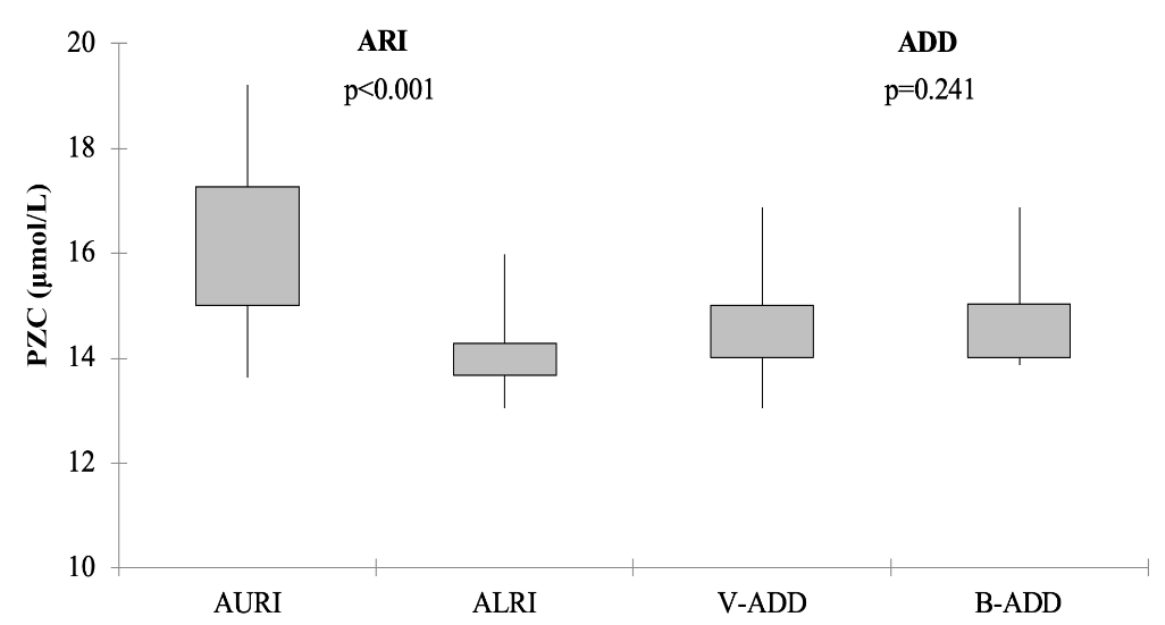

Figure 2. PZC according to past medical history

The PZC values in children with giardiasis, AOM, and viral exanthem are presented in table 2.

Table 2. The PZC in children with other infectious diseases

\begin{tabular}{cccc}
\hline \multirow{2}{*}{ Parameter } & \multicolumn{2}{c}{ PZC $(\boldsymbol{\mu m o l} / \mathbf{L}), \mathbf{M} \pm \mathbf{S D}$} & \multirow{2}{*}{$\boldsymbol{p}$} \\
\cline { 2 - 3 } & Present & Absent & \\
\hline Giardiasis & $15.36 \pm 1.42$ & $14.72 \pm 1.13$ & 0.015 \\
\hline AOM & $14.32 \pm 1.02$ & $15.48 \pm 1.35$ & $<0.001$ \\
\hline Viral exanthem & $15.24 \pm 1.39$ & $14.94 \pm 1.28$ & 0.30 \\
\hline
\end{tabular}

Zinc has multiple roles not entirely known. It is responsible for regulating the activity of enzymes and transcription factors; enters the structure of cell membranes protecting them from the effects of reactive oxygen species and, by its presence at the level of zinc-finger proteins, mediates gene expression. Zinc ion regulates cell growth, differentiation and apoptosis, regulating all processes at the level of the innate and acquired immune system, through zinc transporter, Zrt- and Irt-like proteins, and metallothionein.

Zinc deficiency is responsible for the imbalance of the functioning of the enzymatic system, the immune system, the failure of growth and development at the cellular level. Clinical features of low concentration of zinc are anorexia, lethargy, growth failure, alopecia, rough skin, delayed wound healing, skin lesions, male hypogonadism in adolescents, neurosensory disorders, hepatosplenomegaly, bacterial (fungal) infections, behaviour and endocrine disorders. Death can occur in severe forms of acrodermatitis enteropathica.

Several biomarkers have been proposed to evaluate the zinc status in the human body. The most commonly used were serum, plasma, and urinary zinc concentration, zinc concentration in different cells, zinc concentration in hair, zinc-dependent enzyme activity or concentration of different hormones.

The plasma values are reflecting more accurately the real status of the subjects, compared with those in the serum. The differences are explained by the presence of the clot formation stage, necessary in the process of obtaining the serum. During this stage, the serum can be contaminated with large amounts of zinc from platelets or red blood cells. From the same quantity of blood, is obtained plasma quantity $15-20 \%$ higher than serum. This is an advantage for children, where the amount of blood collected should be as small as possible. PZC varies depending on the dietary intake of zinc. In the case of excessive zinc intake, the regulation of zinc homeostasis prevents the maintenance of a high PZC for a long time. PZC is influenced by the time of day in which the samples are collected and the presence of acute infections. Studies have shown that healthy subjects have a circadian rhythm of 
zincemia, according to which zinc has maximum values between 7 and $10 \mathrm{am}$. Acute infections cause a decrease in the zincemia.

In the study group, PZC values were $99.34 \pm 8.9 \mu \mathrm{g} / \mathrm{dL}(15.20 \pm 1.37 \mu \mathrm{mol} / \mathrm{L})$. The obtained values were within the age-related reference interval. A percentage of $79.56 \%$ of PZC values were falling within this range. The minimum normal value of PZC using this method was $9.8 \mu \mathrm{mol} / \mathrm{L}$. In 2009, Fahan et al. reported PZC values of $99.97 \pm 10.2 \mu \mathrm{g} / \mathrm{dL}$, in a study carried out on a group of 75 healthy children, under 14 years, from Pakistan [35]. In a 2012 study, conducted on a group of 2115 healthy children, ages 6 months - 18 years, from Utah, USA, Chia-Ni et al., found PZC values of $89 \pm 17 \mu \mathrm{g} / \mathrm{dL}$ [36]. There are no data on the value of PZC in the population aged 0-3 years from Europe until now $[37,38]$.

In the present study, children with ALRI in the last 6 months had a statistically significant lower PZC mean value than those with AURI in the same period $(14.10 \pm 0.75 \mu \mathrm{mol} / \mathrm{L}$ versus $15.97 \pm 1.43$ $\mu \mathrm{mol} / \mathrm{L})$. This finding could be associated with the role of zinc to maintain mucosal integrity, differentiation and maturation of $\mathrm{T}$ cells, proliferation of $\mathrm{B}$ cells and cytokine synthesis.

Zinc deficiency induces disorders in the functionality of the immune system which will predispose to subsequent infections. Associated, the low level of zinc may be secondary to the decrease in the concentration of serum albumin, which occurs as a result of inflammatory processes within ALRI, albumin being recognized as a zinc transporter [39]. The difference between the serum zinc values in case of children with AURI versus ALRI can be explained by the longer evolution and recovery from ALRI or by the fact that subjects with ALRI may already have lower zinc values that predispose to ALRI, either in the context of repeated respiratory infections, or secondary to insufficient intake, knowing the fact that zinc does not deposit in the human body.

Rady et al. concluded in 2013, during a study on 40 Egyptian children, aged 3-144 months that PZC decreases as the severity of the ALRI increases [40]. In a Cochrane analysis conducted in 2011, on 13 therapeutic trials and 966 participants with viral respiratory infections, the reduction of the duration, of the disease severity and of the antibiotics use in subjects treated with zinc was shown [30]. The antiviral effect of zinc is mediated by $\mathrm{Il}_{2}, \mathrm{TNF}-\alpha$, and IFN- $\gamma$ synthesized by $\mathrm{TH}_{1}$ cells. Bhandari et al. argue in a study on 2482 children from India, aged 6-30 months, that zinc administration over a period of 4 months decreases the incidence of acute pneumonia and hospitalization for this pathology [41]. Ibraheem et al. claim also low values of PZC for 120 children with ALRI, aged 2-60 months, from Nigeria, compared with healthy subjects [42].

The present research did not reveal statistically significant differences between the values of PZC in children with $\mathrm{V}$-ADD versus B-ADD, in the last six months. The medical literature has shown discordance, referring to the role of zinc in the prevention and treatment of ADD in children. In a Cochrane study, conducted on 33 trials and 10,841 children, no favourable effects were found after zinc administration in the case of children suffering by ADD, but without zinc deficiency [43]. On the other hand, Ahmadipour et al., in a study conducted in 2019 on 146 infants with V-ADD from Iran, sustain the positive effect of zinc administration on the duration, evolution and complications of the disease [44].

In this research, the values of PZC in the group of children with parasitosis in the last 6 months were statistically significantly lower than those obtained in the group without this pathology. Giardiasis can induce nonspecific symptoms such as loss of appetite, diarrhoea and vomiting, which may lead to decreased absorption of micronutrients from the diet and chronic inflammation [9, 45]. Medical literature presents contradictory results. In a study from 2011, conducted by Abou-Shady et $a l$., using blood samples from 30 Egyptian children 1-10 years old with giardiasis, shown lower PZC values compared with those from healthy subjects [24]. Quihui et al., in a study conducted in 2010 on 114 school children in Mexico, argue that the serum zinc level in subjects infected with giardia does not differ significantly from those without parasitic infection [46].

AOM affects more frequently children, and among them, those under the age of 3 are in the risk group for this pathology. Bacterial or viral respiratory infections are involved in the aetiology of this 
disease. Zinc is responsible for the optimal response of the immune system to infections. Its deficiency, secondary to the consumption of zinc in different infectious processes, associated with poor intake due to febrile states associated with inappetence and dyspeptic syndrome particularly in children, predisposes the human body to respiratory infections and their complications. The obtained results for PZC in children with AOM were significantly statistically lower than in the children without this pathology in the last three months. The medical literature is contradictory, some recognizing the effect of zinc to prevent recurrences in AOM in young children [47].

Viral exanthem is the rash that occurs in infectious viral diseases, commonly found in young children. This category includes diseases such as measles, rubella, chickenpox, fifth disease, roseola infantum, Gianotti-Crosti syndrome, molluscum contagiosum, and hand-foot-mouth disease. There were not observed significant differences between PZC values in children who had a history of viral exanthems and those without this pathology. The medical studies performed until now do not support definitive conclusions regarding the role of zinc in this disease.

\section{Conclusions}

In the children aged 0-3 years from the area of Bihor County, Romania, the values recorded for PZC were $15.20 \pm 1.37 \mu \mathrm{mol} / \mathrm{L}$, with limits between 13.05-20.6 $\mu \mathrm{mol} / \mathrm{L}$, values falling within normal limits and proving the absence of zinc deficiency in the investigated population. The values of zincemia have been significantly influenced by the presence of ALRI, AOM or giardiasis in the past medical history and they were not influenced by the viral or bacterial aetiology of ADD or viral exanthemas. The role of zinc in the child pathology is not fully understood yet, further studies being needed for this purpose.

\section{References}

1.BAO, S., KNOELL, D.L., Zinc modulates cytokine-induced lung epithelial cell barrier permeability. Am. J. Physiol. Lung Cell Mol. Physiol., 291(6), 2006, L1132-1141.

2.FINAMORE, A., MASSIMI, M., CONTI DEVIRGILIIS, L., MENGHERI, E., Zinc deficiency induces membrane barrier damage and increases neutrophil transmigration in Caco-2 cells, $J$. Pharmacol. Exp. Therapeut., 294(3), 2000, 997-1008.

3.ADAMO, A.M., ZAGO, M.P., MACKENZIE, G.G., AIMO, L., KEEN, C.L., KEENAN, A., et al., The role of zinc in the modulation of neuronal proliferation and apoptosis, Neurotox. Res., 17(1), 2010, $1-14$.

4.JOHN, E., LASKOW, T.C., BUCHSER, W.J., PITT, B.R., BASSE, P.H., BUTTERFIELD, L.H., et al., Zinc in innate and adaptive tumor immunity, J. Transl. Med., 8(118), 2010, 2-16.

5.SHEIKH, A., SHAMSUZZAMAN, S., AHMAD, S.M., NASRIN, D., NAHAR, S., ALAM, M.M., et al., Zinc influences innate immune responses in children with enterotoxigenic Escherichia coliinduced diarrhea. J. Nutr., 140(5), 2010, 1049-1056.

6.SJOBlOM, B., POLENTARUTTI, M., DJINOVIC-CARUGO, K., Structural study of X-ray induced activation of carbonic anhydrase, Proc. Natl. Acad. Sci. USA, 106(26), 2009, 10609-10613.

7.NEGRUT, N., KHAN, S.A., BUNGAU, S., ZAHA, C., CORB ARON, R.A., BRATU, O., DIACONU, C.C., IONITA-RADU, F., Diagnostic challenges in gastrointestinal infections, Rom. $J$. Mil. Med., 123(2), 2020, 83-90.

8.FRAKER, P.J., KING, L.E., LAAKKO, T., VOLLMER, T.L., The dynamic link between the integrity of the immune system and zinc status, J. Nutr., 130(5S Suppl), 2000, 1399S-406S.

9.PRASAD, A.S., Zinc: role in immunity, oxidative stress and chronic inflammation, Curr Opin Clin Nutr Metab Care, 12(6), 2009, 646-52.

10.MIHAESCU, G., Immunology and immunochemistry, Bucharest, Universitatii Ed., 2011, 129.

11.BROWN, K., RIVERA, J.A., BHUTTA, Z., GIBSON, R.S., KING, J.C., LONNERDAL, B., et al., International Zinc Nutrition Consultative Group (IZiNCG) Technical Document. Assessment of the 
Risk of Zinc Deficiency in Populations and Options for Its Control, Food Nutri. Bull., 25, 2004, S99203.

12.HAASE, H., RINK, L., The Immune System and the Impact of Zinc During Aging, Immun. Ageing., 6(9), 2009, 9.

13.IWATA, T., INCEFY, G.S., TANAKA, T., FERNANDES, G., MENENDEZ-BOTET, C.J., PIH, K., et al., Circulating thymic hormone levels in zinc deficiency., Cell Immunol., 47(1), 1979,100-105.

14.ABDEL-DAIM, M.M., EL-TAWIL, O.S., BUNGAU, S.G., ATANASAOV, A.G., Applications of Antioxidants in Metabolic Disorders and Degenerative Diseases: Mechanistic Approach, Oxid. Med. Cell. Longev., 2019, 2019, 1-3. https://doi.org/10.1155/2019/4179676

15.LEITE, S.A., Inhibitors of human collagenase, MMP1. Ecletica Quimica., 34, 2009, 87-102.

16.MUZZIOLI, M., STECCONI, R., MORESI, R., PROVINCIALI, M., Zinc improves the development of human CD34+ cell progenitors towards NK cells and increases the expression of GATA-3 transcription factor in young and old ages, Biogerontol., 10(5), 2009, 593-604.

17.INTERNATIONAL ZINC NUTRITION CONSULTATIVE GROUP (IZiNCG). 2010. http://www.izincg.org/news/stunting Accesed 30 Oct. 2019.

18.FRAKER, P.J., KING, L.E., Reprogramming of the immune system during zinc deficiency, Annu Rev Nutr., 24, 2004, 277-98.

19.DE SAREEN, S., GROPPER, J.L.S., GROFF, J.L., Advanced nutrition and human metabolism. $7^{\text {th }}$ Ed., 2017, 499-508.

20.GAMMOH, N.Z., RINK, L., Zinc in Infection and Inflammation, Nutrients, 9(6), 2017, 624.

21.LAZZERINI, M., RONFANI, L., Oral Zinc for Treating Diarrhoea in Children, Cochrane Database Syst. Rev., 6, 2012, CD005436.

22.***THE UNITED NATIONS CHILDREN'S FUND (UNICEF)/WORLD HEALTH ORGANIZATION (WHO), 2013. https://www.who.int/maternal_child_adolescent/documents/global_ action_plan_pneumonia_diarrhoea/en/. Accesed 22 Oct. 2019.

23.HAIDER, B.A., BHUTTA, Z.A., The effect of therapeutic zinc supplementation among young children with selected infections: a review of the evidence, Food Nutr. Bull., 30 (1 Suppl.), 2009, S4159.

24.CODREAN, A., DUMITRASCU, D.L., CODREAN, V., TIT, D.M., BUNGAU, S., ALEYA, S., RUS, M., FRATILA, O., NISTOR, CSEPPENTO, D.C., ALEYA, L., NEGRUT, N., Epidemiology of human giardiasis in Romania: A 14 years survey, Sci. Tot Environ., 705, 2020. https://doi.org/10.1016/j.scitotenv.2019.135784

25.LONG, K.Z., ROSADO, J.L., MONTOYA, Y., DE LOURDES SOLANO, M., HERTZMARK, E., DUPONT, HL, SANTOS, J.I., Effect of vitamin A and zinc supplementation on gastrointestinal parasitic infections among Mexican children, Pediatrics, 120(4), 2007, e846-55. doi: 10.1542/ peds.2006-2187

26.ASTIAZARAN-GARCIA, H., INIGO-FIGUEROA， G., QUIHUI-COTA, L., ANDUROCORONA, I., Crosstalk between zinc status and Giardia infection: a new approach, Nutrients, 7(6), 2015, 4438-4452. doi: 10.3390/nu7064438

27.SANCHEZ-GUILLEN MDEL, C., PEREZ-FUENTES, R., SALGADO-ROSAS, H., RUIZARGUELlES, A., ACKERS, J., SHIRE, A., TALAMAS-ROHANA, P., Differentiation of Entamoeba histolytica/Entamoeba dispar by PCR and their correlation with humoral and cellular immunity in individuals with clinical variants of amoebiasis, Am. J. Trop. Med. Hyg., 66(6), 2002, 731-737. doi: 10.4269/ajtmh.2002.66.731

28.AYDEMIR, T.B., LIUZZI, J.P., MCCLELLAN, S., COUSINS, R.J., Zinc transporter ZIP8 (SLC39A8) and Zinc influence IFN-gamma expression in activated human T cells, J. Leukoc. Biol., 86(2), 2009, 337-348. doi: 10.1189/jlb.1208759

29.LASSI, Z.S., MOIN, A., BHUTTA, Z.A., Zinc supplementation for the prevention of pneumonia in children aged 2 months to 59 months, Cochrane Database Syst. Rev., 12, 2016. doi: 10.1002/ 14651858.CD005978.pub3. 
30.SHAKER, S.M., FATHY, H., ABDELALL, E.K.A., SAID, A.S.A., The effect of zinc and Vitamin A supplements in treating and reducing the incidence of upper respiratory tract infections in children, Natl. J. Physiol. Pharm. Pharmacol., 8(7), 2018, 1010-1017. doi: 10.5455/njppp. 2018.8. 0104206032018

31.SINGH, M., DAS, R.R., Zinc for the common cold, Cochrane Database Syst. Rev., 2, 2011, CD001364. doi: 10.1002/14651858.CD001364.pub3.

32.ZAHA, D.C., BUNGAU, S., UIVAROSAN, D., TIT, D.M., MAGHIAR, T.A., MAGHIAR, O., PANTIS, C., FRATILA, O., RUS, M., VESA, C.M., Antibiotic consumption and microbiological epidemiology in surgery departments: results from a single study center. Antibiotics-Basel, 9(2), 2020, 81. https://doi.org/10.3390/antibiotics9020081

33.ZAHA, D.C., BUNGAU, S., ALEYA, S., TIT, D.M., VESA, C.M., POPA, A.R., PANTIS, C., MAGHIAR, O.A., BRATU, O.G., FURAU, C., MOLERIU, R.D., PETRE, I., ALEYA, L., What antibiotics for what pathogens? The sensitivity spectrum of isolated strains in an intensive care unit, Sci. Tot. Environ., 687, 2019, 118-127. https://doi.org/10.1016/j.scitotenv.2019.06.076

34.ABBA, K., GULANI, A., SACHDEV, H.S., Zinc supplements for preventing otitis media, Cochrane Database Syst. Rev., 2, 2010, Cd006639. doi: 10.1002/14651858.CD006639.pub2.

35.JAVED, F., ASHGAR, A., SHEIKH, S., ASGHAR, M., NADEEM, H., MALIK, B.A., Comparison of serum Zinc levels between healthy and malnourished children, Ann. Punjab Med. Coll., 3(2), 2009, 139-143.

36.LIN, C.N., WILSON, A., CHURCH, B.B., EHMAN, S., ROBERTS, W.L., MCMILLIN, G.A., Pediatric reference intervals for serum copper and zinc, Clin. Chim. Acta., 413(5-6), 2012, 612-615. doi: 10.1016/j.cca.2011.12.005

37.NOVAKOVIC, R., CAVELAARS, A.E., BEKKERING, G.E., ROMAN-VINAS, B., NGO, J., GURINOVIC, M., et al. Micronutrient intake and status in Central and Eastern Europe compared with other European countries, results from the EURRECA network, Public Health Nutr., 16(5), 2013, 824840.doi: 10.1017/S1368980012004077

38.MORAN, V.H., STAMMERS, A.L., MEDINA, M.W., PATEL, S., DYKES, F., SOUVEREIN, O.W., et al., The Relationship between Zinc Intake and Serum/Plasma Zinc Concentration in Children: A Systematic Review and Dose-Response Meta-Analysis, Nutrients, 4(8), 2012, 841-858. doi: 10.3390/nu4080841

39.HANDING, K.B., SHABALIN, I.G., KASSAAR, O., KHAZAIPOUL, S., BLINDAUER, C.A., STEWART, A.J., et al., Circulatory zinc transport is controlled by distinct interdomain sites on mammalian albumins, Chem. Sci., 7(11), 2016. doi: 10.1039/C6SC02267G

40.RADY, H.I., RABIE, W.A., RASSLAN, H.A., EL AYADI, A.A., Blood zinc levels in children hospitalized with pneumonia: A cross sectional study, Egypt J. Chest Dis. Tuberc., 62, 2013, 697-700.

41.BHANDARI, N., BAHL, R., TANEJA, S., STRAND, T., MOLBAK, K., ULVIK, R.J., et al. Effect of routine zinc supplementation on pneumonia in children aged 6 months to 3 years: randomised controlled trial in an urban slum, BMJ, 324, (7350), 2002, 1358. doi: 10.1136/bmj.324.7350.1358

42.IBRAHEEM, R.M., JOHNSON, A.B.R., ABDULKARIM, A.A., BILIAMINU, S.A., Serum zinc levels in hospitalized children with acute lower respiratory infections in the north-central region of Nigeria, Afr. Health Sci., 14(1), 2014, 136-142. doi: 10.4314/ahs.v14i1.21

43.LAZZERINI, M., WANZIRA, H., Oral zinc for treating diarrhoea in children. Cochrane Database Syst Rev., 12, 2016. doi: 10.1002/14651858

44.AHMADIPOUR, S., MOHSENZADEH, A., ALIMADADI, H., SALEHNIA, M., FALLAHI, A., Treating Viral Diarrhea in Children by Probiotic and Zinc Supplements, Pediatr. Gastroenterol. Hepatol. Nutr., 22(2), 2019, 162-170. doi: 10.5223/pghn.2019.22.2.162

45.COTTON, J.A., AMAT, C.B., BURET, A.G., Disruptions of Host Immunity and Inflammation by Giardia Duodenalis: Potential Consequences for Co-Infections in the Gastro-Intestinal Tract, Pathogens, 44(4), 2015, 764-792. https://doi.org/10.3390/pathogens4040764 
46.QUIHUI, L., MORALES, G.G., MENDEZ, R.O., LEYVA, J.G., ESPARZA, J., VALENCIA, M.E., Could giardiasis be a risk factor for low zinc status in schoolchildren from northwestern Mexico? A cross-sectional study with longitudinal follow-up, BMC Public Health, 10(1), 2010, 85. doi: 10.1186/1471-2458-10-85.

47.GULANI, A., SACHDEV, H.S., Zinc supplements for preventing otitis media, Cochrane Database Syst. Rev., 6, 2014.

$\overline{\text { Manuscript received: } 13.11 .2020}$ 